Correspondence

Kwok-yung Yuen

hkumicro@hkucc.hku.hk

Received 10 December 2008

Accepted 3 May 2009

\section{Guidelines for interpretation of 16S rRNA gene sequence-based results for identification of medically important aerobic Gram-positive bacteria}

\author{
Patrick C. Y. Woo, ${ }^{1,2,3} \dagger$ Jade L. L. Teng, ${ }^{3} \dagger$ Jeff K. L. Wu, ${ }^{3}$ \\ Fion P. S. Leung, ${ }^{3}$ Herman Tse, ${ }^{1,2,3}$ Ami M. Y. Fung, ${ }^{3}$ \\ Susanna K. P. Lau ${ }^{1,2,3}$ and Kwok-yung Yuen ${ }^{1,2,3}$ \\ ${ }^{1}$ State Key Laboratory of Emerging Infectious Diseases, University of Hong Kong, Hong Kong SAR \\ ${ }^{2}$ Research Centre of Infection and Immunology, University of Hong Kong, Hong Kong SAR \\ ${ }^{3}$ Department of Microbiology, University of Hong Kong, Hong Kong SAR
}

\begin{abstract}
This study is believed to be the first to provide guidelines for facilitating interpretation of results based on full and $527 \mathrm{bp} 16 \mathrm{~S}$ rRNA gene sequencing and MicroSeq databases used for identifying medically important aerobic Gram-positive bacteria. Overall, full and 527 bp 16S rRNA gene sequencing can identify 24 and $40 \%$ of medically important Gram-positive cocci (GPC), and 21 and $34 \%$ of medically important Gram-positive rods (GPR) confidently to the species level, whereas the full-MicroSeq and 500-MicroSeq databases can identify 15 and $34 \%$ of medically important GPC and 14 and $25 \%$ of medically important GPR confidently to the species level. Among staphylococci, streptococci, enterococci, mycobacteria, corynebacteria, nocardia and members of Bacillus and related taxa (Paenibacillus, Brevibacillus, Geobacillus and Virgibacillus), the methods and databases are least useful for identification of staphylococci and nocardia. Only $0-2$ and $2-13 \%$ of staphylococci, and 0 and $0-10 \%$ of nocardia, can be confidently and doubtfully identified, respectively. However, these methods and databases are most useful for identification of Bacillus and related taxa, with 36-56 and 11-14\% of Bacillus and related taxa confidently and doubtfully identified, respectively. A total of 15 medically important GPC and 18 medically important GPR that should be confidently identified by full $16 \mathrm{~S}$ rRNA gene sequencing are not included in the full-MicroSeq database. A total of 9 medically important GPC and 21 medically important GPR that should be confidently identified by 527 bp $16 \mathrm{~S}$ rRNA gene sequencing are not included in the 500-MicroSeq database. 16S rRNA gene sequence results of Gram-positive bacteria should be interpreted with basic phenotypic tests results. Additional biochemical tests or sequencing of additional gene loci are often required for definitive identification. To improve the usefulness of the MicroSeq databases, bacterial species that can be confidently identified by 16S rRNA gene sequencing but are not found in the MicroSeq databases should be included.
\end{abstract}

\section{INTRODUCTION}

Since its first use three decades ago, 16S rRNA gene sequencing has become one of the indispensable pillars in the polyphasic approach to bacterial classification and novel bacteria discovery (Woo et al., 2008a). In the last decade, the technology has further developed beyond the research realm and matured into a clinical application for bacterial identification. Despite its increasing use in

†These authors contributed equally to this work.

Abbreviations: GPC, Gram-positive cocci; GPR, Gram-positive rods.

Tables of sequence comparison and identification data are available as supplementary material with the online version of this paper. reference laboratories, one of the major limitations to its wider use is the difficulty associated with interpretation of 16S rRNA gene sequence results. The use of 16S rRNA gene sequencing for bacterial identification depends on a significant inter-species difference and a small intra-species difference in 16S rRNA gene sequences. Therefore, one of the major limitations is that when two different bacterial species share almost the same $16 \mathrm{~S}$ rRNA gene sequence; this technique alone would not be useful for distinguishing them confidently.

Aimed at facilitating $16 \mathrm{~S}$ rRNA gene sequence interpretation, the MicroSeq 500 16S rRNA gene bacterial identification system (MicroSeq; Perkin-Elmer Applied 
Biosystems) has been designed, using a $527 \mathrm{bp}$ fragment in the $5^{\prime}$ end of the 16S rRNA gene (Cloud et al., 2004; Fontana et al., 2005; Lau et al., 2006; Patel et al., 2000; Tang et al., 1998, 2000; Woo et al., 2003c). Recently, a full 16S rRNA gene sequence (full-MicroSeq) database (version 2.0) has also been generated. However, the MicroSeq databases do not take into account bacterial species sharing similar 16S rRNA gene sequences that would not be confidently identified by $16 \mathrm{~S}$ rRNA gene sequence analysis. Furthermore, the accuracy of identification is further limited by the bacterial species included in the database, as bacterial species that are not included in the database would never be determined as the identity of an isolate.

In view of these limitations, 3 years ago we started to systematically evaluate the usefulness of full and $527 \mathrm{bp}$ $16 \mathrm{~S}$ rRNA gene sequencing and the MicroSeq databases for identification of various groups of medically important bacteria. Recently, we have published the results for medically important anaerobes (Woo et al., 2007). In this article, we describe the results of an evaluation of the usefulness of full and $527 \mathrm{bp} 16 \mathrm{~S}$ rRNA gene sequencing and the MicroSeq databases for identification of 409 medically important aerobic Gram-positive bacteria. Practical points when using such technologies for identification of these bacteria are also discussed.

\section{METHODS}

$16 S$ rRNA gene sequences of medically important aerobic Gram-positive bacteria. The species of medically important aerobic Gram-positive bacteria included in this study include all the 409 species of the 59 genera of medically important aerobic Gram-positive cocci (GPC) and Gram-positive rods (GPR) listed in the most recent edition of the Manual of Clinical Microbiology (Murray et al., 2007). For each bacterial species, a list of the 16S rRNA gene sequence was retrieved from the GenBank database. In the list, the most representative 16S rRNA gene sequence for each species was chosen for analysis according to the following criteria: (a) strains with good phenotypic characterization, such as the type strains, were preferred to those without good phenotypic characterization; (b) strains isolated from humans were preferred to those isolated from animals or the environment; (c) sequences with fewer undetermined bases were preferred to those with more undetermined bases; and (d) longer sequences, especially those with better coverage of the $5^{\prime}$ end, were preferred to shorter sequences and those with poorer coverage of the $5^{\prime}$ end.

Comparison of full 16S rRNA gene sequences of medically important aerobic Gram-positive bacteria. The percentage differences of the 16S rRNA gene sequences among the different species in the same group/genus of medically important GPC and GPR were determined by pairwise alignment using CLUSTAL $\mathrm{w}$ (Thompson et al., 1994). For sequences with undetermined bases, other 16S rRNA gene sequences of the same species were retrieved and the undetermined bases were manually amended. If there was no other 16S rRNA gene sequence for the same species, the positions of the undetermined bases were deleted in the analysis.

Comparison of 527 bp 165 rRNA gene sequences of medically important aerobic Gram-positive bacteria. The 527 bp sequences that should be amplified by the primers of MicroSeq were extracted from the full $16 \mathrm{~S}$ rRNA gene sequences. The percentage differences of the resultant partial 16S rRNA gene sequences among the different species in the same group/genus of medically important GPC and GPR were determined by pairwise alignment using CLUSTAL $\mathrm{W}$ (Thompson et al., 1994).

Definitions. A bacterium species is defined as 'confidently identified by $16 \mathrm{~S}$ rRNA gene sequencing' if there is $>3 \%$ difference between the $16 \mathrm{~S}$ rRNA gene sequence of the species and those of other medically important bacteria species. A bacterium species is defined as 'not confidently identified by $16 \mathrm{~S}$ rRNA gene sequencing' if there is $<2 \%$ difference between the 16S rRNA gene sequence of the species and that of one or more medically important aerobic Gram-positive bacterium species. A bacterium species is defined as 'only doubtfully identified by $16 \mathrm{~S}$ rRNA gene sequencing' if there is $2-3 \%$ difference between the 16S rRNA gene sequence of the species and that of one or more medically important aerobic Gram-positive bacterium species.

\section{RESULTS}

The percentage differences of the full and $527 \mathrm{bp} 16 \mathrm{~S}$ rRNA gene sequences among the different groups of medically important aerobic Gram-positive bacteria are shown in Supplementary Table S1(a-k) (available with the online journal).

\section{Full 16S rRNA gene sequencing for identification of medically important aerobic Gram-positive bacteria}

None and $1(2 \%)$ of 46 staphylococci, $8(20 \%)$ and 9 $(22 \%)$ of 41 streptococci, none and $5(17 \%)$ of 30 enterococci, $32(65 \%)$ and $7(14 \%)$ of 49 GPC other than staphylococci, streptococci and enterococci, $2(3 \%)$ and 7 (9\%) of 74 mycobacteria, $9(24 \%)$ and $12(32 \%)$ of 38 corynebacteria, none and 1 (3\%) of 31 nocardia, $16(44 \%)$ and $4(11 \%)$ of 36 members of Bacillus and related taxa (Paenibacillus, Brevibacillus, Geobacillus and Virgibacillus), and $24(38 \%)$ and $11(17 \%)$ of 64 GPR other than mycobacteria, corynebacteria, nocardia and members of Bacillus and related taxa can be confidently and doubtfully identified by full $16 \mathrm{~S}$ rRNA gene sequencing, respectively (Table 1, Supplementary Table S2a-k, available with the online journal).

\section{Full-MicroSeq database for identification of medically important aerobic Gram-positive bacteria}

None and $1(2 \%)$ of 46 staphylococci, $7(17 \%)$ and 8 $(20 \%)$ of 41 streptococci, none and $4(13 \%)$ of 30 enterococci, $18(37 \%)$ and $4(8 \%)$ of 49 GPC other than staphylococci, streptococci and enterococci, $2(3 \%)$ and 5 $(7 \%)$ of 74 mycobacteria, $3(8 \%)$ and $8(21 \%)$ of 38 corynebacteria, none of 31 nocardia, $13(36 \%)$ and 4 $(11 \%)$ of 36 members of Bacillus and related taxa (Paenibacillus, Brevibacillus, Geobacillus and Virgibacillus), and $15(23 \%)$ and $5(8 \%)$ of 64 GPR other than mycobacteria, corynebacteria, nocardia and members of Bacillus and related taxa can be confidently and doubtfully 
Table 1. Number and percentage of species of major groups of medically important Gram-positive bacteria confidently identified by full 16S rRNA gene sequence, 527 bp 16S rRNA gene sequence and the MicroSeq databases

\begin{tabular}{|c|c|c|c|c|c|}
\hline \multirow[t]{2}{*}{ Bacterial genera } & \multirow[t]{2}{*}{ Total no. of species } & \multicolumn{4}{|c|}{ No. (\%) of species confidently identified } \\
\hline & & $\begin{array}{c}\text { Full 16S rRNA } \\
\text { gene sequencing }\end{array}$ & $\begin{array}{c}\text { Full-MicroSeq } \\
\text { database }\end{array}$ & $\begin{array}{l}527 \text { bp 16S rRNA } \\
\text { gene sequencing }\end{array}$ & $\begin{array}{c}\text { 500-MicroSeq } \\
\text { database }\end{array}$ \\
\hline \multicolumn{6}{|l|}{ Gram-positive cocci } \\
\hline Staphylococcus & 46 & $0(0)$ & $0(0)$ & $1(2)$ & $1(2)$ \\
\hline Streptococcus & 41 & $8(20)$ & $7(17)$ & $19(46)$ & $18(44)$ \\
\hline Enterococcus & 30 & $0(0)$ & $0(0)$ & $8(27)$ & $7(23)$ \\
\hline Abiotrophia and Granulicatella & 4 & $1(25)$ & $1(25)$ & $2(50)$ & $1(25)$ \\
\hline Gemella & 4 & $1(25)$ & $0(0)$ & $2(50)$ & $2(50)$ \\
\hline \multicolumn{6}{|l|}{ Gram-positive rods } \\
\hline Mycobacterium & 74 & $2(3)$ & $2(3)$ & $9(12)$ & $8(11)$ \\
\hline Corynebacterium & 38 & $9(24)$ & $3(8)$ & $15(39)$ & $11(29)$ \\
\hline Nocardia & 31 & $0(0)$ & $0(0)$ & $0(0)$ & $0(0)$ \\
\hline Bacillus and related taxa & 36 & $16(44)$ & $13(36)$ & $20(56)$ & $17(47)$ \\
\hline
\end{tabular}

*Paenibacillus, Brevibacillus, Geobacillus and Virgibacillus.

identified by the full-MicroSeq database, respectively (Table 1, Supplementary Table S2a-k, available with the online journal).

\section{7 bp 165 rRNA gene sequencing for identification of medically important aerobic Gram-positive bacteria}

One (2\%) and $6(13 \%)$ of 46 staphylococci, $19(46 \%)$ and $5(12 \%)$ of 41 streptococci, $8(27 \%)$ and $1(3 \%)$ of 30 enterococci, $38(78 \%)$ and $4(8 \%)$ of 49 GPC other than staphylococci, streptococci and enterococci, $9(12 \%)$ and $15(20 \%)$ of 74 mycobacteria, $15(39 \%)$ and $5(13 \%)$ of 38 corynebacteria, none and $3(10 \%)$ of 31 nocardia, 20 (56\%) and $5(14 \%)$ of 36 members of Bacillus and related taxa (Paenibacillus, Brevibacillus, Geobacillus and Virgibacillus), and $38(59 \%)$ and 6 (9\%) of 64 GPR other than mycobacteria, corynebacteria, nocardia and members of Bacillus and related taxa can be confidently and doubtfully identified by 527 bp $16 \mathrm{~S}$ rRNA gene sequencing, respectively (Table 1, Supplementary Table S2 a-k, available with the online journal).

\section{0-MicroSeq database for identification of medically important aerobic Gram-positive bacteria}

One (2\%) and $5(11 \%)$ of 46 staphylococci, $18(44 \%)$ and $3(7 \%)$ of 41 streptococci, $7(23 \%)$ and none of 30 enterococci, $31(63 \%)$ and $3(6 \%)$ of 49 GPC other than staphylococci, streptococci and enterococci, $8(11 \%)$ and $11(15 \%)$ of 74 mycobacteria, $11(29 \%)$ and $3(8 \%)$ of 38 corynebacteria, none and $2(6 \%)$ of 31 nocardia, 17 (47\%) and $5(14 \%)$ of 36 members of Bacillus and related taxa (Paenibacillus, Brevibacillus, Geobacillus and Virgibacillus), and $25(39 \%)$ and $4(6 \%)$ of 64 GPR other than mycobacteria, corynebacteria, nocardia and members of Bacillus and related taxa can be confidently and doubtfully identified by the 500 -MicroSeq database, respectively (Table 1, Supplementary Table S2 a-k available with the online journal).

\section{DISCUSSION}

The major difficulties and controversies in interpreting $16 \mathrm{~S}$ rRNA gene sequence data relate to the assignment of bacterial species based on similarity search results, as no threshold values are available as for DNA-DNA hybridization (Petti, 2007). As different bacterial species are likely to evolve at different rates, there has been no agreement on a universal cut-off for bacterial species delineation. In 1994, Stackebrandt and Goebel proposed a $97 \%$ similarity level for bacterial speciation using 16S rRNA gene sequence (Stackebrandt \& Goebel, 1994). Although in the study by Drancourt et al. (2000) a $>99$ and $>97 \%$ sequence similarity was used as the cut-off for species and genus identification, respectively, the authors indicated that these sharp values were mainly made for practical purposes for interpretation of their large sequence dataset. On the other hand, Janda and Abbott suggested that a minimum of $>99 \%$, and ideally $>99.5 \%$, sequence similarity be used for species identification in their recommended guidelines (Janda \& Abbott, 2007). Although different studies have identified groups of bacteria for which 16S rRNA gene sequences are not discriminative enough, no study has attempted to solve this problem in a systematic way. Moreover, the use of public databases such as GenBank can be problematic in that errors in sequence data are not uncommon. For example, the strain with GenBank accession number Z26896 was claimed to be Staphylococcus haemolyticus. However, the sequence has 
highest nucleotide identities to sequences of 16S rRNA genes of Staphylococcus aureus, rather than other strains of Staphylococcus haemolyticus, and no results of phenotypic characterization were given for this strain. Therefore, the true identity of this strain is difficult to ascertain. In the present study and a previous one (Woo et al., 2007), we used $>3,2-3$ and $<2 \%$ differences between the most representative $16 \mathrm{~S}$ rRNA gene sequence of species obtained from GenBank and those of other medically important bacteria to indicate the degree of confidence when using $16 \mathrm{~S}$ rRNA sequence for identification of medically important bacterial species. When there is $2-3 \%$ difference between the 16S rRNA gene sequence of a bacterial species and a closely related one, the degree of $16 \mathrm{~S}$ rRNA gene sequence homogeneity in different strains of that species becomes very important in determining whether $16 \mathrm{~S}$ rRNA gene sequencing is able to identify the bacterium to the species level. More importantly, medically important bacterial species with similar 16S rRNA gene sequences were also identified (Supplementary Table S2 a-k available with the online journal), so that the users can easily note the species that may be potentially confused based on $16 \mathrm{~S}$ rRNA gene sequence analysis. Further phenotypic tests and/or sequencing of other gene loci can be performed to differentiate these species.

For species identification, 16S rRNA gene sequence results of aerobic Gram-positive bacteria should be interpreted cautiously with basic phenotypic tests results, and additional biochemical tests or sequencing of additional gene loci are often required for definitive identification. Overall, using $3 \%$ base difference as the cut-off, full and 527 bp $16 \mathrm{~S}$ rRNA gene sequencing can only identify 24 and $40 \%$ of medically important GPC and 21 and $34 \%$ of medically important GPR confidently to the species level. This is apparently different from the results reported in some other studies, in which up to 83 and $92 \%$ of the isolates can be assigned to species level (Mignard \& Flandrois, 2006; Bosshard et al., 2006). In some studies, the difference was due to the use of different cut-offs for confident identification; whereas in others, the difference was a result of a larger proportion of bacterial strains, other than Gram-positive bacteria, that can be confidently identified. The higher percentage of bacteria that can be confidently identified by 527 bp $16 \mathrm{~S}$ rRNA gene sequencing than full $16 \mathrm{~S}$ rRNA gene sequencing is a result of the non-random distribution of base difference along the 16S rRNA gene. For some genera, such as staphylococci, mycobacteria and nocardia, both full and 527 bp 16S rRNA gene sequencing can identify $<13 \%$ of bacteria confidently. Therefore, in order to prevent misinterpretation of $16 \mathrm{~S}$ rRNA gene sequence results, they should always be interpreted in the context of basic phenotypic test results. Moreover, key phenotypic tests, that can help distinguish between 'the closest match' by $16 \mathrm{~S}$ rRNA gene sequencing and medically important bacterial species with similar 16S rRNA gene sequences as listed in Supplementary Table S2 $(\mathrm{a}-\mathrm{k})$ (available with the online journal), should be performed for differentiation of these possibilities (Woo et al., 2001, 2003d; Lau et al., 2002; Cloud et al., 2005). For example, in our previous study on Tsukamurella conjunctivitis, $16 \mathrm{~S}$ rRNA gene sequencing was able to identify the various isolates as Tsukamurella to the genus level, but all Tsukamurella species possess $>99 \%$ nucleotide identities with each other. Phenotypic tests have to be performed to distinguish among the various Tsukamurella species (Woo et al., 2003d). Alternatively, sequencing of other gene loci can be performed for identification of species in these genera. In fact, another gene locus, groEL, has been shown to be better than 16S rRNA gene for identification of staphylococci and mycobacteria (Kwok et al., 1999; Goh et al., 1996; Ringuet et al., 1999). Other genes, such as tuf, $d n a J$ and $r p o B$, and secAl have also been used for identification of staphylococci, mycobacteria and nocardia, respectively (Heikens et al., 2005; Yamada-Noda et al., 2007; Adékambi et al., 2003; Conville et al., 2006). This conclusion of the necessity for support of 16S rRNA gene sequence results by other identification methodologies, such as phenotypic tests and/or sequencing other gene targets, is in line with the recommendations given by the Clinical and Laboratory Standards Institute, although different cut-offs were used in their recommendations (CLSI, 2008). One has to be particularly cautious if $16 \mathrm{~S}$ rRNA gene sequencing is used for culture-negative infections, such as infective endocarditis, as no isolate is available for further phenotypic testing (Gauduchon et al., 2003; Kotilainen et al., 2006). Furthermore, some medically important Gram-positive bacteria, such as Streptococcus sinensis, have been reported as a cause of infective endocarditis in Asia and Europe with the oral cavity documented to be the reservoir, but are still not yet included in the Manual of Clinical Microbiology (Woo et al., 2002, 2004b, 2008b; Uçkay et al., 2007; Faibis et al., 2008). One must bear in mind that these bacteria not yet included in the Manual of Clinical Microbiology may also be the identity of an isolate. Particular attention has to be paid if there is discrepancy between $16 \mathrm{~S}$ rRNA gene sequence and phenotypic test results.

Despite its relatively low confidence for species identification, 16S rRNA gene sequencing is very useful for identification of medically important Gram-positive bacteria to the genus level, especially for some groups of Gram-positive bacteria notoriously difficult to identify by phenotypic methods. Although some genera of Grampositive bacteria, such as Mycobacterium and Nocardia, possess unique phenotypic characteristics, such as acidfastness, for their easy identification to the genus level, most streptococcus-like Gram-positive cocci, such as Granulicatella, Abiotrophia, Gemella and Helcococcus, are particularly difficult for genus identification using phenotypic tests. In our experience, most commercial systems failed to identify most of our clinical isolates of Granulicatella, Abiotrophia, Gemella and Helcococcus to the genus level (Woo et al., 2003a, b, 2005). Gram-positive bacterial isolates that possess unusual phenotypic profiles 
Table 2. Medically important Gram-positive bacteria that can be confidently identified by full or $527 \mathrm{bp}$ 16S rRNA gene sequencing but are not included in the MicroSeq databases

\begin{tabular}{|c|c|c|}
\hline \multirow[t]{2}{*}{ Bacterial genera } & \multicolumn{2}{|c|}{ Bacterial species } \\
\hline & $\begin{array}{c}\text { Not included in } \\
\text { full-MicroSeq database }\end{array}$ & $\begin{array}{c}\text { Not included in } \\
\text { 500-MicroSeq database }\end{array}$ \\
\hline \multicolumn{3}{|c|}{ Gram-positive cocci } \\
\hline \multirow{3}{*}{ Aerococcus } & A. christensenii & A. sanguinicola \\
\hline & A. sanguinicola & A. urinaehominis \\
\hline & A. urinaehominis & \\
\hline Dolosicoccus & D. paucivorans & \\
\hline Dolosigranulum & D. pigrum & D. pigrum \\
\hline Enterococcus & & E. italicus \\
\hline \multirow[t]{4}{*}{ Facklamia } & F. hominis & \\
\hline & F. ignava & \\
\hline & F. languida & \\
\hline & F. sourekii & \\
\hline Gemella & G. bergeri & \\
\hline Granulicatella & & G. elegans \\
\hline \multirow[t]{2}{*}{ Helcococcus } & H. kunzii & H. sueciensis \\
\hline & H. sueciensis & \\
\hline Ignavigranum & I. ruoffiae & I. ruoffiae \\
\hline Rothia & R. mucilaginosa & \\
\hline Streptococcus & S. hyovaginalis & S. hyovaginalis \\
\hline Tetragenococcus & & T. solitarius \\
\hline \multicolumn{3}{|c|}{ Gram-positive rods } \\
\hline Actinomadura & A. pelletieri & A. latina \\
\hline Amycolatopsis & A. palatopharyngis & A. palatopharyngis \\
\hline Arthrobacter & A. scleromae & A. scleromae \\
\hline \multirow[t]{2}{*}{ Bacillus } & B. fumarioli & B. fumarioli \\
\hline & B. subterraneus & B. subterraneus \\
\hline \multirow[t]{2}{*}{ Brevibacterium } & B. luteolum & B. luteolum \\
\hline & & B. sanguinis \\
\hline Cellulomonas & & C. denverensis \\
\hline \multirow[t]{6}{*}{ Corynebacterium } & C. atypicum & C. atypicum \\
\hline & C. durum & C. durum \\
\hline & C. glucuronolyticum & C. kroppenstedtii \\
\hline & C. imitans & C. resistens \\
\hline & C. kroppenstedtii & \\
\hline & C. resistens & \\
\hline Erysipelothrix & E. inopinata & E. inopinata \\
\hline Janibacter & J. sanguinis & J. sanguinis \\
\hline Leifsonia & L. aquatica & \\
\hline Microbacterium & & M. resistens \\
\hline Mycobacterium & & M. heckeshornense \\
\hline Paenibacillus & P. hongkongensis & P. hongkongensis \\
\hline Rhodococcus & & R. gordoniae \\
\hline Streptomyces & & S. thermovulgaris \\
\hline \multirow[t]{2}{*}{ Zimmermannella } & Z. alba & Z. alba \\
\hline & Z. bifida & Z. bifida \\
\hline
\end{tabular}

also led to the same problem (Woo et al., 2003e, 2004a). In these cases, $16 \mathrm{~S}$ rRNA gene sequencing would be extremely useful for genus identification and narrowing down the identification to a few possible species that possess similar $16 \mathrm{~S}$ rRNA gene sequences.
When using the MicroSeq databases for bacterial identification, additional attention has to be paid to possible medically important bacterial species that are not included in the database, and the accuracies reported for MicroSeq for various groups of Gram-positive bacteria might have 
been overestimated. The percentage of Gram-positive bacteria estimated to be confidently identified by the MicroSeq databases in this study is low compared to the accuracies reported for selected groups of Gram-positive bacteria in the literature (Patel et al., 2000; Tang et al., 2000; Mellmann et al., 2003). This is mainly because the MicroSeq databases do not take into account bacteria with similar 16S rRNA gene sequences, which can confuse the identity of the bacterium. For example, in two studies that assessed the usefulness of 500-MicroSeq for identification of mycobacteria and nocardia, clinical isolates of Mycobacterium chelonae, Mycobacterium tuberculosis, Mycobacterium marinum, Nocardia asteroides, Nocardia nova and Nocardia farcinica were considered successfully identified by 500-MicroSeq (Patel et al., 2000; Mellmann et al., 2003), but the present study indicated that in fact there are Mycobacterium and Nocardia species with similar $16 \mathrm{~S}$ rRNA gene sequences. In fact, it is well known that the $16 \mathrm{~S}$ rRNA gene is probably not the best target for identifying mycobacteria and nocardia, and alternative gene targets, such as $d n a J$ and $\sec A 1$, as mentioned above, have been used for their identification (Yamada-Noda et al., 2007; Conville et al., 2006). Therefore, in the present study and our previous one on anaerobes (Woo et al., 2007), supplementary note is given to indicate those bacteria that cannot be confidently identified but are included in the MicroSeq databases, symbolized by $?^{\mathrm{c}}$ and $?^{\mathrm{f}}$ in Supplementary Table S2 (a-k) (available with the online journal). In addition to this problem, the MicroSeq databases are also defective in that they do not contain a significant proportion of medically important species. To make our results more user-friendly, supplementary data is also included to indicate whether the inability of the MicroSeq databases to identify a particular bacterium is due to the species not being included in the MicroSeq databases, symbolized by $x^{\mathrm{a}}$ and $\mathrm{x}^{\mathrm{d}}$ in Supplementary Table S2 (a-k) (available with the online journal), or high 16S rRNA gene sequence similarity ( $>98 \%$ nucleotide identity) to a closely related species, symbolized by $x^{\mathrm{b}}$ and $x^{\mathrm{e}}$ in Supplementary Table S2 $(\mathrm{a}-\mathrm{k})$ (available with the online journal). To improve the usefulness of the MicroSeq databases, bacterial species that can be confidently identified by $16 \mathrm{~S}$ rRNA gene sequencing but are not found in the MicroSeq databases should be included (Table 2). These include 15 medically important GPC and 18 medically important GPR that should be confidently identified by full $16 \mathrm{~S}$ rRNA gene sequencing but are not included in the full-MicroSeq database, and 9 medically important GPC and 21 medically important GPR that should be confidently identified by 527 bp 16S rRNA gene sequencing but are not included in the 500-MicroSeq database (Table 2).

\section{ACKNOWLEDGEMENTS}

This work is partly supported by the Committee of Research and Conference Grants and University Development Fund, University of Hong Kong.

\section{REFERENCES}

Adékambi, T., Colson, P. \& Drancourt, M. (2003). rpoB-based identification of nonpigmented and late-pigmenting rapidly growing mycobacteria. J Clin Microbiol 41, 5699-5708.

Bosshard, P. P., Zbinden, R., Abels, S., Böddinghaus, B., Altwegg, M. \& Böttger, E. C. (2006). 16S rRNA gene sequencing versus the API 20 NE system and the VITEK 2 ID-GNB card for identification of nonfermenting Gram-negative bacteria in the clinical laboratory. J Clin Microbiol 44, 1359-1366.

Cloud, J. L., Conville, P. S., Croft, A., Harmsen, D., Witebsky, F. G. \& Carroll, K. C. (2004). Evaluation of partial $16 \mathrm{~S}$ ribosomal DNA sequencing for identification of nocardia species by using the MicroSeq 500 system with an expanded database. J Clin Microbiol 42, 578-584.

Cloud, J. L., Hoggan, K., Belousov, E., Cohen, S., Brown-Elliott, B. A., Mann, L., Wilson, R., Aldous, W., Wallace, R. J., Jr \& Woods, G. L. (2005). Use of the MGB Eclipse system and SmartCycler PCR for differentiation of Mycobacterium chelonae and M. abscessus. J Clin Microbiol 43, 4205-4207.

CLSI (2008). Interpretive Criteria for Identification of Bacteria and Fungi by DNA Target Sequencing, approved guideline MM18-A. Wayne, PA: Clinical and Laboratory Standards Institute.

Conville, P. S., Zelazny, A. M. \& Witebsky, F. G. (2006). Analysis of secAl gene sequences for identification of Nocardia species. J Clin Microbiol 44, 2760-2766.

Drancourt, M., Bollet, C., Carlioz, A., Martelin, R., Gayral, J. P. \& Raoult, D. (2000). 16S ribosomal DNA sequence analysis of a large collection of environmental and clinical unidentifiable bacterial isolates. J Clin Microbiol 38, 3623-3630.

Faibis, F., Mihaila, L., Perna, S., Lefort, J. F., Demachy, M. C., Le Flèche-Matéos, A. \& Bouvet, A. (2008). Streptococcus sinensis: an emerging agent of infective endocarditis. J Med Microbiol 57, 528-531.

Fontana, C., Favaro, M., Pelliccioni, M., Pistoia, E. S. \& Favalli, C. (2005). Use of the MicroSeq 500 16S rRNA gene-based sequencing for identification of bacterial isolates that commercial automated systems failed to identify correctly. J Clin Microbiol 43, 615-619.

Gauduchon, V., Chalabreysse, L., Etienne, J., Célard, M., Benito, Y., Lepidi, H., Thivolet-Béjui, F. \& Vandenesch, F. (2003). Molecular diagnosis of infective endocarditis by PCR amplification and direct sequencing of DNA from valve tissue. J Clin Microbiol 41, 763-766.

Goh, S. H., Potter, S., Wood, J. O., Hemmingsen, S. M., Reynolds, R. P. \& Chow, A. W. (1996). HSP60 gene sequences as universal targets for microbial species identification: studies with coagulase-negative staphylococci. J Clin Microbiol 34, 818-823.

Heikens, E., Fleer, A., Paauw, A., Florijn, A. \& Fluit, A. C. (2005). Comparison of genotypic and phenotypic methods for species-level identification of clinical isolates of coagulase-negative staphylococci. $J$ Clin Microbiol 43, 2286-2290.

Janda, J. M. \& Abbott, S. L. (2007). 16S rRNA gene sequencing for bacterial identification in the diagnostic laboratory: pluses, perils, and pitfalls. J Clin Microbiol 45, 2761-2764.

Kotilainen, P., Heiro, M., Jalava, J., Rantakokko, V., Nikoskelainen, J., Nikkari, S. \& Rantakokko-Jalava, K. (2006). Aetiological diagnosis of infective endocarditis by direct amplification of rRNA genes from surgically removed valve tissue. An 11-year experience in a Finnish teaching hospital. Ann Med 38, 263-273.

Kwok, A. Y., Su, S. C., Reynolds, R. P., Bay, S. J., Av-Gay, Y., Dovichi, N. J. \& Chow, A. W. (1999). Species identification and phylogenetic relationships based on partial HSP60 gene sequences within the genus Staphylococcus. Int J Syst Bacteriol 49, 1181-1192. 
Lau, S. K., Woo, P. C., Woo, G. K. \& Yuen, K. Y. (2002). Catheterrelated Microbacterium bacteremia identified by $16 \mathrm{~S}$ rRNA gene sequencing. J Clin Microbiol 40, 2681-2685.

Lau, S. K., Ng, K. H., Woo, P. C., Yip, K. T., Fung, A. M., Woo, G. K., Chan, K. M., Que, T. L. \& Yuen, K. Y. (2006). Usefulness of the MicroSeq 500 16S rDNA bacterial identification system for identification of anaerobic Gram positive bacilli isolated from blood cultures. J Clin Pathol 59, 219-222.

Mellmann, A., Cloud, J. L., Andrees, S., Blackwood, K., Carroll, K. C., Kabani, A., Roth, A. \& Harmsen, D. (2003). Evaluation of RIDOM, MicroSeq, and GenBank services in the molecular identification of Nocardia species. Int J Med Microbiol 293, 359-370.

Mignard, S. \& Flandrois, J. P. (2006). 16S rRNA sequencing in routine bacterial identification: a 30-month experiment. J Microbiol Methods 67, 574-581.

Murray, P. R., Baron, E. J., Jorgensen, J. H., Landry, M. L. \& Pfaller, M. A. (2007). Manual of Clinical Microbiology, 9th edn. Washington, DC: American Society for Microbiology.

Patel, J. B., Leonard, D. G., Pan, X., Musser, J. M., Berman, R. E. \& Nachamkin, I. (2000). Sequence-based identification of Mycobacterium species using the MicroSeq $50016 \mathrm{~S}$ rDNA bacterial identification system. J Clin Microbiol 38, 246-251.

Petti, C. A. (2007). Detection and identification of microorganisms by gene amplification and sequencing. Clin Infect Dis 44, 1108-1114.

Ringuet, H., Akoua-Koffi, C., Honore, S., Varnerot, A., Vincent, V., Berche, P., Gaillard, J. L. \& Pierre-Audigier, C. (1999). hsp65 sequencing for identification of rapidly growing mycobacteria. J Clin Microbiol 37, 852-857.

Stackebrandt, E. \& Goebel, B. M. (1994). Taxonomic note: a place for DNA-DNA reassociation and $16 \mathrm{~S}$ rRNA sequence analysis in the present species definition in bacteriology. Int J Syst Bacteriol 44, 846849.

Tang, Y. W., Ellis, N. M., Hopkins, M. K., Smith, D. H., Dodge, D. E. \& Persing, D. H. (1998). Comparison of phenotypic and genotypic technique for identification of unusual aerobic pathogenic gramnegative bacilli. J Clin Microbiol 36, 3674-3679.

Tang, Y. W., Von Graevenitz, A., Waddington, M. G., Hopkins, M. K., Smith, D. H., Li, H., Kolbert, C. P., Montgomery, S. O. \& Persing, D. H. (2000). Identification of coryneform bacterial isolates by ribosomal DNA sequence analysis. J Clin Microbiol 38, 1676-1678.

Thompson, J. D., Higgins, D. G. \& Gibson, T. J. (1994). CLUSTAL W: improving the sensitivity of progressive multiple sequence alignment through sequence weighting position-specific gap penalties and weight matrix choice. Nucleic Acids Res 22, 4673-4680.

Uçkay, I., Rohner, P., Bolivar, I., Ninet, B., Djordjevic, M., Nobre, V., Garzoni, C. \& Schrenzel, J. (2007). Streptococcus sinensis endocarditis outside Hong Kong. Emerg Infect Dis 13, 1250-1252.

Woo, P. C., Leung, A. S., Leung, K. W. \& Yuen, K. Y. (2001). Identification of slide-coagulase positive, tube-coagulase negative Staphylococcus aureus by $16 \mathrm{~S}$ ribosomal RNA gene sequencing. Mol Pathol 54, 244-247.
Woo, P. C., Tam, D. M., Leung, K. W., Lau, S. K., Teng, J. L., Wong, M. K. \& Yuen, K. Y. (2002). Streptococcus sinensis sp. nov., a novel Streptococcus species isolated from a patient with infective endocarditis. J Clin Microbiol 40, 805-810.

Woo, P. C., Fung, A. M., Lau, S. K., Chan, B. Y., Chiu, S. K., Teng, J. L., Que, T. L., Yung, R. W. \& Yuen, K. Y. (2003a). Granulicatella adiacens and Abiotrophia defectiva bacteraemia characterised by $16 \mathrm{~S}$ rRNA gene sequencing. J Med Microbiol 52, 137-140.

Woo, P. C., Lau, S. K., Fung, A. M., Chiu, S. K., Yung, R. W. \& Yuen, K. Y. (2003b). Gemella bacteraemia characterized by $16 \mathrm{~S}$ ribosomal RNA gene sequencing. J Clin Pathol 56, 690-693.

Woo, P. C., Ng, K. H., Lau, S. K., Yip, K. T., Fung, A. M., Leung, K. W., Tam, D. M., Que, T. L. \& Yuen, K. Y. (2003c). Usefulness of the MicroSeq 500 16S ribosomal DNA-based bacterial identification system for identification of clinically significant bacterial isolates with ambiguous biochemical profiles. J Clin Microbiol 41, 1996-2001.

Woo, P. C., Ngan, A. H., Lau, S. K. \& Yuen, K. Y. (2003d). Tsukamurella conjunctivitis: a novel clinical syndrome. J Clin Microbiol 41, 33683371.

Woo, P. C., Teng, J. L., Lau, S. K., Lum, P. N., Leung, K. W., Wong, K. L., Li, K. W., Lam, K. C. \& Yuen, K. Y. (2003e). Analysis of a viridans group strain reveals a case of bacteremia due to Lancefield group $\mathrm{G} \alpha$ hemolytic Streptococcus dysgalactiae subsp. equisimilis in a patient with pyomyositis and reactive arthritis. J Clin Microbiol 41, 613-618.

Woo, P. C., Tam, D. M., Lau, S. K., Fung, A. M. \& Yuen, K. Y. (2004a). Enterococcus cecorum empyema thoracis successfully treated with cefotaxime. J Clin Microbiol 42, 919-922.

Woo, P. C., Teng, J. L., Leung, K. W., Lau, S. K., Tse, H., Wong, B. H. \& Yuen, K. Y. (2004b). Streptococcus sinensis may react with Lancefield group F antiserum. J Med Microbiol 53, 1083-1088.

Woo, P. C., Tse, H., Wong, S. S., Tse, C. W., Fung, A. M., Tam, D. M., Lau, S. K. \& Yuen, K. Y. (2005). Life-threatening invasive Helcococcus kunzii infections in intravenous drug users and ermA-mediated erythromycin resistance. J Clin Microbiol 43, 6205-6208.

Woo, P. C., Chung, L. M., Teng, J. L., Tse, H., Pang, S. S., Lau, V. Y., Wong, V. W., Kam, K. L., Lau, S. K. \& Yuen, K. Y. (2007). In silico analysis of $16 \mathrm{~S}$ ribosomal RNA gene sequencing-based methods for identification of medically important anaerobic bacteria. J Clin Pathol 60, 576-579.

Woo, P. C., Lau, S. K., Teng, J. L., Tse, H. \& Yuen, K. Y. (2008a). Then and now: use of $16 \mathrm{~S}$ rDNA gene sequencing for bacterial identification and discovery of novel bacteria in clinical microbiology laboratories. Clin Microbiol Infect 14, 908-934.

Woo, P. C., Teng, J. L., Tsang, S. N., Tse, C. W., Lau, S. K. \& Yuen, K. Y. (2008b). The oral cavity as natural reservoir for Streptococcus sinensis. Clin Microbiol Infect 14, 1075-1079.

Yamada-Noda, M., Ohkusu, K., Hata, H., Shah, M. M., Nhung, P. H., Sun, X. S., Hayashi, M. \& Ezaki, T. (2007). Mycobacterium species identification - a new approach via dnaJ gene sequencing. Syst Appl Microbiol 30, 453-462. 